\title{
The Research on Teaching Reform of the "University Computer Basic" Course In Police Active Colleges
}

\author{
YU Dongmei \\ Basic Courses Teaching Department, Armed Police Academy, Lang fang City, Hebe Province, \\ China \\ Liu_xijun@sohu.com
}

Keywords: Basic computer course Police active college Computational thinking

\begin{abstract}
For university computer basic course in police active colleges, this paper studies and analyzes the exiting problems, what including the education ideas being not clear, contents divorcing from practical application, status downing et. It puts forward the countermeasures. And, it discusses how to carry out the in teaching. This has a certain reference function to deepen the computational thinking reform.
\end{abstract}

\section{Introduction}

Police active academy shoulders the task that training qualified personnel for the Public Security Forces. Public Security Forces contains multiple kinds such as border police, fire police and security guard police and so on. Every kind needs high-quality talent in its field. In the current and future, as being an essential basic skill, the computer and is an important part in the personnel training. Meanwhile, the information technology construction in the armed police has made rapid development, which puts forward higher requirements to the serving officers' application skills. Therefore, the "university computer basic" course in the police active colleges must continue to carry out reform, and should at the forefront in all of reforms.

\section{Problems in Course}

After years of teaching research and practice on this course, I found the following problems in the curriculum implementation process.

\section{Large Differences in Student Basis}

On the one hand, along with socio-economic and technological development, computer basic courses moved ahead to primary and secondary schools, which making the freshmen having a certain theoretical basis and operational capability, so the curriculum must meet the higher requirements, such as how to set the content system, how to implement teaching programs et.

On the other hand, the source of students admitted by the police active force college is complex. Here are some that participated in the common entrance examination to the highest line; also some are soldiers from the grass-roots forces. The former has relatively high computer literacy, like learning theoretical knowledge. The soldier students are weaker more; while some from developed areas have higher computer literacy than that from Xinjiang, Tibet and other remote areas. Just because being the large differences, which make teaching organization and implement difficult.

\section{Teaching Reform Relative Lag}

First, the idea of teaching reform is lagging behind. Since 1997, basic computer education experiences the two big changes. At present, the nationwide colleges and universities' basic education field is enjoying an upsurge of computational thinking reforms, although no clear standards and goals, but it can also be regarded as the third revolution prelude. However, the majority of front-line police colleges' faculty value teaching practice, slight theory. They do not realize the significance and importance of the new change, study and integrate the new educational philosophy less. Not to advance is to go back, already in the lag position.

Secondly, the teaching method is monotony. Under the influence of compressed lessons hours, in order to complete teaching task, most teachers exist " chalk and talk " phenomenon in the teaching 
process, because the students basic differences, appears part of the students "hunger" , another part of the students " Surfeit ".

\section{From Teaching and Practical Application}

As actual force needs and information technology construction, it requires students that not only reach a certain computer literacy, but also have targeted and special computer skills for the different kinds of police. It can be said, the talent trained in the police active academy should have distinct occupational characteristics. But most colleges use the national textbooks, education and occupation practice seriously out of line, which results the students learning interest is small, the school is not satisfied with the effect, cannot meet the needs of the army.

\section{Course Status Declining}

The University computer courses steering committee of Ministry of education clearly points out that the university computer basic course is a compulsory general course in Colleges and universities, its importance is no doubt. However, in some police colleges, because of teaching reform backward, and divorced from the practical application, the students' learning enthusiasm is not high, not interested. Colleges generate questions about the curriculum, class is dropping lower and lower, the content has been adjusted for several times, and even turned the compulsory courses into the standard course. Course status is declining, seriously affecting the implementation and reform teaching.

\section{Around Computational Thinking, Combined with Multi-level Teaching Reform Strategy}

To change the status quo, to solve problems and improve the quality of teaching, not overnight, you need to complete the gradual deepening even require repeated practice and explore the best and latest way. In response to these problems, I believe that these multiple levels should be research and practice.

\section{Computational Thinking Idea as Teaching Reform Foundation}

After years of teaching university computer basic course, education idea appears serious deviation, some people think it is a computer operating lesson, and even is office training courses; course status has been seriously affected. Until 2006, Yizhen Zhou professor, the director of Carnegie Mellon University Computer Science Department, proposed computational thinking concept. Computational thinking is the use of the basic concepts of computer science to solve problems, design systems and understand the thinking of human behavior [1]. Computational thinking essence is abstraction and automation, as everyone must have "read, write, count" (referred to as 3R) capability, as everyone must have the computational thinking skills. The ultimate goal of basic computer courses is to train college students' computational thinking ability. Course knowledge embodies many computational thinking methods, such as computer hardware components, various algorithms (sorting, recursion, etc.).

Previous teaching, in fact, has penetrated the computational thinking, but they are unconscious, is not clear, you need to pay attention to the philosophy, method and guide to computational thinking concepts at the core of learning, to train students getting calculating thinking ability.

\section{Rearrange Course Content System}

"University Computer Basics " course content system is the theory + practice mode, theoretical part includes computer literacy, system components, operating systems theory, networks , algorithms and data structures, and program design based theory ; operations mainly office software and windows operating system. Integrate computational thinking reform, training students identify problems, analyze problems, problem-solving skills, do not need to complete the overthrow of the existing system of curriculum content, but re-sort, adjust the content structure, some need increase theoretical knowledge guidance, such as the computer system composition, should appropriately increase the depth and breadth of teaching content. For operation parts because most students have a foundation, so it can reduce classroom hours, distribute task to do in spare times, independent by students themselves, then directed by the instructor in practical class and check learning. Save this hours to the theory parts, so that makes up the insufficient hours problem.

With the deepening reform, it can gradually change the course content and implementation. 


\section{Reform Teaching Methods and Means}

In teaching, to arouse students ' interest in learning, to develop their applications , innovation and computational thinking ability, teachers' guiding role is very important. if teaching methods is single, the students will very less able to take the initiative to explore and solve problems, not to mention a passion for learning. I found if introduce practical cases about serving in the duty, their interest very strong, involved in learning initiative significantly strengthened. So should reform teaching methods and means in the multi-angle, multi-level.

(1)Use Topics in Classroom Teaching

Topics teaching both cover all knowledge, and easy to melt in computational thinking, can also organic the latest computer technology, methods and new applications introduced to the students. It full account of the knowledge and interest to improve students' computer literacy. It is not a simple repetition of high school, but, at a new height of new understanding. Teachers can set aside some time to discuss with the students for thematic elements, students answer questions in a timely manner. With Classroom teaching knowledge object being center, teachers dominate the entire learning process, teachers develop clear teaching objectives, complete control over the progress of teaching, which conducive to teaching management specification, the scale of the learning activities, and provide good collective learning environment and atmosphere. In this teaching method is easy to improve communication between teachers, students, help them form a correct outlook on life, world outlook, values and collective spirit.

(2) Teaching Mode Stratification

With the method of hierarchical teaching to solve the problem that student foundation is different, the learning progress is uneven. Individualized teaching is necessary to comply with the principles of. On the basis of the better local students, can increase the teaching guide, increase knowledge and expand symposium; On the basis of the weaker soldiers students, more attention should be paid to basic theory knowledge and operating skills of learning. According to the different situation of each team, The teacher flexible changes teaching methods and arrangements.

(3) Three-Dimensional Practice

This has two levels of meaning. On the one hand, the basic knowledge and theory take two approaches: 1) Establish a network assessment exam system for the students to learn; 2 )with virtual reality technology, flash and other multimedia technology ,experiment the basic principles of computer hardware and software, gradually forms the experimental database for students to learn , so as to understanding the basic principles and concepts in the interaction process.

On the other hand, for basic skills training, the use of task -driven model is given. It has two level: 1) the base practice, it requires students clear target, master basic skills and points. For different kinds of police practice, teachers design different tasks, give detailed operational requirements, give the results of the model and detailed operational guidance, this is mainly for the weaker students; 2 ) the improved practice, according to the points, for different kinds of police, teachers design different topics, not to mention the detailed operational requirements and guidance, only give a reference model for students , this is for the better.

(4) Modular Teaching Content

As different kinds of police require different computer skills, this need modularize teaching content. In class, teachers customize content for the p students' professional needs.

(5) Multidimensional Teaching Case

To determine the standard of knowledge, according to the different requirements of different kinds of occupation and practical application, design rich teaching case, which includes text, picture, video etc. Teachers teaching and students practice all can reference, every professional student can find his own want to learn case.

\section{Integration of Teaching Resources}

The basic principle of university education is to develop students ' self-learning ability, training students how to use computers searching information and take the initiative to complete a specific task, which is also demands of the force information construction. Therefore, you must take advantage of campus network as a platform for classroom instruction and hands-on practice. 
Construction of university computer online education platform, provides self-help resources search, study and practice, evaluation, including electronic courseware, case base and other sub-professional curriculum resources. Students in the classroom, dormitory and computer room all can enter the learning platform to study.

\section{Changes in Assessment Methods}

The traditional curriculum evaluation is based on the final exam add usually results, in order to cultivate students application ability, innovation ability and the computational thinking ability, the respondent, student exchanges and the experiment, seminar report as student assessment reference, and increase its weight.

\section{Conclusion}

Due to the continuous development of computer technology itself, the social changes in computer skill needs, need university computer foundation course to constantly change. In this process, we should strengthen the education idea, find the reform direction, improving teaching methods. The computer basic course in police colleges need train applied talents with the computational thinking, creative thinking. To achieve this goal, we need reform from multiple levels and aspects, including the teaching ideas, teaching methods, teaching means and so on. This process needs to continue research, exploration and practice, has a long way to go.

\section{References}

[1] Yizhen Zhou: Computational thinking, Chinese Computer Communications Society, 2007, 3(11)

[2] Peizeng Gong, Zhiqiang Yang: Computational Thinking Training in University Basic Computer Teaching,

[3] Boqin Feng: Exploration the Problem of Thinking Ability to Practice, China University Teaching 2012,9

[4] Guoxing Peng, Qiang Liu, Yanhui Zhu: Optimizing Teaching Contents of College Computer Basic Course Based on Thought Computation, Enterprise Science And Technology \& Development, 2012,1

[5] Hanquan Lu, Qinming He, Jingchun Xu: Content Design of the " University Computer Basis" Course based on Computational thinking, China University Teaching 2012,9 